\title{
Analysis of Genetical Diversity of Some of the Tetraploides Potato Cultivars Grown in Iran
}

\author{
Mehdi Nasr Esfahai ${ }^{*}$, Mashid Rostam Pour ${ }^{2}$, Alireza Pazoki ${ }^{2}$ \\ ${ }^{1}$ Agriculture and Natural Resourses research Center, Isfahan, Iran; ${ }^{2}$ Department of Agronomy and Plant breading, Shahr-e-Rey \\ Branch, Islamic Azad University, Tehran, Iran. \\ Email: *mne2011@gamil.com
}

Received September $25^{\text {th }}$, 2012; revised November $12^{\text {th }}$, 2012; accepted November $20^{\text {th }}, 2012$

\begin{abstract}
The genetical diversity of potato, Solanum tuberosum was assessed using morphological traits. To verify, how this diversity is distributed among the main potato varieties grown in Iran. A total of eleven potato varieties, Ramose, Sante, Shepody, Marfona, Maradona, Milova, Santana, Boren, Cosima, Granola and Agria, were evaluated under vivo and situ experimental conditions in Isfahan, conditions, Iran. Seven phenological, floral and morphological vegetative aerial descriptors, Growth Rate $=$ CGR, Net Assimilation Rate $=$ NAR, Leaf Area Duration $=$ LAD, Leaf Area Ratio $=$ LAR and specific Leaf Area = SLA were recorded. The descriptors were evaluated by SAS Software and their means comparison by DMRT test. Certain defined groups were observed, indicating that the diversity of the cultivars are structured with a considerable morphological variation in between the varieties with a very high significant growth indices.
\end{abstract}

Keywords: Potato; Genetic; Phenology; Morphology; Varieties

\section{Introduction}

Potato (Solanum tuberosum) is one of the main and strategic products and stands in fourth position after wheat, rice and corn. It has also a special role in feeding people of under developed countries. Thus, for making secure feeding, increasing efficiency of this strategic product seems necessary. Potato is from the family of Solanaceae with 26 genus and 2800 species. Most of its species are from tropical and southern parts of America. Potato is belonged to big and varied Solanum genus; with 2000 species. Cultivated potatoes are belonged to $S$. tuberosum with 180 varieties, which produce tubers [1].

Most commercial varieties of $S$. tuberosum are tetraploid. There are two subspecies: tubersum and andigena whereas, tubersum is with world distribution expended. Root system of $S$. tuberosum is relatively weak and it is expanded easily in light soil with sandy clay texture. Methods of propagation of potato are asexual with tubers division and, sexual with true potato seed culture [1].

In propagation with tuber, the adventurous roots are formed from the base of divided tubers primarily, and then root and stem are initiated from top of underground nodes of tubers. In case of true potato seed sowing, plant will have a tiny tap root and stolons with lateral branches, and some replicates roots initiated from stolen. The stem

${ }^{*}$ Corresponding author. in S. tuberosum is green, herbaceous, and already thick. It's thickness is already $2-2.25 \mathrm{Cm}$. Stem also has some trichomes. Plants which are formed from true seed has main stem with lateral branches but, plants from tuber seed has many main and lateral stems [2].

The leaves are compound pinnate. That is; a leaflet can be seen on the top of the main petiole. The main petiole is herbaceous and has light green color with 7 - 9 leaflets. The leaflets are ovate, irregular, entire margin and little lobed with dark green color. The veins of leaflets are clear with light green color. The leaflets have trichomes on both the sides with very short petiole [3].

The flowers of $S$. tuberosum are two types; actionmorph and zygomorph. There are five sepals, soft or corky and with green, red, or purple color and different length. The petioles are also different in length size. The corolla are star shape, rectangular, or circular. In case of color, most of them are white but, they are clear in red, purple, blue, yellow, and pink type [1].

The stamens are 5 and most of them have long and column anther with yellow or orange color. They show related groups which are individual or divergent. The pollen grains are expended from the top of anther. The fruit is inform of burry epigenous with two carpels and 5 $8 \mathrm{~mm}$ thickness. Tiny seeds are spread in berry fruit. Modified stem, tuber is the main reserving organ in potato [3]. 
The size of tuber is depending on the kind of variety, soil properties, and also climatic conditions. The potato is commonly circular-elliptical and or oval. The skin of tuber is soft, hard or nettled. The color of the tuber skin is white, and, purple and also pink or yellow. The tuber contains; $75 \%$ or $80 \%$ water, $12 \%$ starch, $1.5 \%$ and or $2 \%$ protein, $2 \%$ or $3 \%$ fiber, salts and also vitamin C [4]. Some lateral stems are horizontally grown on buds of underground stems. The lengths of them are varied and also are the main factor to recognize varieties. S. tuberosum can be produced in different ecological areas, in tropical, subtropical, desert, mountainous, and temperate areas. S. tuberosum is used for feeding herd and human. It contains vitamin $\mathrm{C}$, potassium, calcium, family of vitamin B and a little sodium.

There is no any coherent study on this subject. So, because of the importance of the subject, any types of such studies is unavoidable. This study was carried out on eleven varieties of potato which are under cultivation in both greenhouse and field conditions, for verification of phenological and morphological diversity differentiation.

\section{Material and Method}

For the genetic analaysis phenological and morphological analysis and also testing varieties in field and green house conditions, these experiments were done based on classic method in Isfahan. The treatments were composed of eleven commercial varieties of S. tuberosum growing mainly in Iran; Ramose, Sante, Shepody, Marfona, Maradona, Milova, Santana, Granola, Boren, Cosima, Agria (Table 1). Experimental treatments were based a randomized block design using 4 replicates in the field and 5 replicates in green house.

For preparation of the soil, $20 \mathrm{t} / \mathrm{ha}$ farm yard manures were added into the field soil on January 2010 before plowing. Then, $300 \mathrm{~kg} / \mathrm{ha}$ potassium sulfate, $200 \mathrm{~kg} / \mathrm{ha}$ Super triple phosphate and $350 \mathrm{~kg} / \mathrm{ha}$ ammonium sulfate in the form of chemical fertilizers were added proportionately into the field soil. At the end, the field was divided into 4 replications. There was one raw with 3 meters length and $75 \mathrm{~cm}$ distance. Also, for preparing pots soil, the ratio of 1:1:1 of sand, manure and clay mixed together for the glass house. The pots were sterilized and sufficient NPK was added accordingly [5].

Each variety was sown in a raw. The tubers in the density of 5.33 plants (clons) per square meter were sown with the distance of $20 \mathrm{Cm}$ plant to plant. To avoid soil diseases, tubers were disinfected by fungicide for $3 \mathrm{~min}$ utes in a suspension and each variety was sown in 45 pots. The depth of sowing tubers was $10 \mathrm{~cm}$. In green house, also tubers were disinfected by fungicide for 3 minutes. Watering in the field and green house was based on the temperature and moisture of the soil. For avoiding and controlling early blight disease the fungicides, RTS 2/1000 and Daconil 3/1000 were used. And, for mite pest, the pesticide Neuron $1 / 1000$ and larvin $0.5 / 1000$ were used. For aphid pest, Kenfidor 0.5/1000, and for Bemisia, Diazinon 1/1000 was used [6].

A month after sowing, $150 \mathrm{~kg} / \mathrm{ha}$ Ammonium sulfate in each pot was used. Sampling for determination of understudied factors in the field and green house were done repeatedly, after every two weeks. Varieties; Ramose, Sante, Shepody, Marfona, Maradona in the field and green house were sampled 6 and 5 times respectively. Santana, Maradona, Milova, Boren varieties were sampled 7 times in the field and 6 times in the green house. Also, for Granola, Cosima, Agria the sampling was done 8 times in the field and 7 times in the green house. In

Table 1. The Characteristics of the varieties for analysis of genetical diversity of some of the tetraploides potato.

\begin{tabular}{|c|c|c|c|c|c|c|c|c|c|c|c|}
\hline Characteristics & Agria & Ramose & Granola & Sante & Shepody & Marfona & Sanata & Maradona & Milova & Burren & Cosima \\
\hline Maturity & ME - ML & Lo & Low & ME - ML & E & ME - ML & ME - ML & ML & $\mathrm{Me}$ & ME-ML & ME - ML \\
\hline Dormancy & Lo & $\mathrm{Me}$ & V Lo & Me Lo - Lo & $\mathrm{Me}$ & Lo & Me Lo & Lo & $\mathrm{Me}$ & $\mathrm{Me}$ & Lo - V Lo \\
\hline Foliage development & G & G & Low & Fa G & G & G & $\mathrm{G}$ to $\mathrm{Fa} \mathrm{G}$ & G & Me & G & G \\
\hline Colour of skin & $\mathrm{Y}$ & FaY - OpY & $\mathrm{W}-\mathrm{Y}$ & $\mathrm{Y}$ & C & $\mathrm{Y}$ & $\mathrm{Y}$ & $\mathrm{C}$ & $\mathrm{W}-\mathrm{Y}$ & $\mathrm{W}-\mathrm{Y}$ & $\mathrm{W}-\mathrm{Y}$ \\
\hline Colour of flesh & $\mathrm{Y}$ & $\mathrm{FaY}-\mathrm{PY}$ & $\mathrm{Y}$ & PY & C & PY & PY & $\mathrm{Y}$ & $\mathrm{C}-\mathrm{Y}$ & $\mathrm{FaY}$ & $\mathrm{Y}$ \\
\hline Shape of tubers & Lo - Ov & Lo - Ov & Ov - R & Ov - R- Ov & $\mathrm{L}$ & $\mathrm{R}-\mathrm{Ov}$ & Lo - Ov & $\mathrm{R}-\mathrm{Ov}$ & Ov & R Flat & R Ov - R \\
\hline Shallowness of eyes & Sh & Sh & $\mathrm{Sh}-\mathrm{M}$ & Ra Sh & Sh - Me & Ra Sh & VSh & Ra Sh & Ra Sh & Sh & Sh - Me \\
\hline Size of tubers & $\mathrm{L}$ & $\mathrm{L}$ & $\mathrm{Me}-\mathrm{L}$ & $\mathrm{L}$ & Lo & VL & $\mathrm{L}$ & $\mathrm{L}$ & $\mathrm{L}$ & $\mathrm{L}$ & $\mathrm{L}$ \\
\hline Yield & VH & G - Me & $\mathrm{Me}-\mathrm{H}$ & $\mathrm{H}$ & $\mathrm{Me}$ & VH & G - Me & VH & $\mathrm{H}$ & $\mathrm{H}$ & $\mathrm{Me}-\mathrm{H}$ \\
\hline Dry matter content & G & Fa firm - Fl & $\mathrm{Me}-\mathrm{H}$ & Me - G & $\mathrm{Me}$ & V low - Low & $\mathrm{G}-\mathrm{H}$ & $\mathrm{H}$ & $\mathrm{Me}$ & $\mathrm{Me}-\mathrm{H}$ & $\mathrm{Me}-\mathrm{H}$ \\
\hline Suitable for & Ff & $\mathrm{Ff}$ & $\mathrm{F}, \mathrm{Ch}, \mathrm{Ff}$ & $\mathrm{F} \mathrm{Ch}$ & F, Ff & F, Ch & F ,Ch, Ff & $\mathrm{F}$ & $\mathrm{F}, \mathrm{Ff}$ & F, Ff & $\mathrm{F}, \mathrm{Ff}$ \\
\hline
\end{tabular}

$\mathrm{C}=$ Cream, $\mathrm{Ch}=$ Chips, $\mathrm{E}=$ Early, $\mathrm{F}=$ Fresh, Fa = Fairly, Fl = Floury, Ff = French fries, $\mathrm{G}=\mathrm{Good}, \mathrm{H}=\mathrm{High}, \mathrm{I}=\mathrm{Intermediate}, \mathrm{L}=\mathrm{Large}, \mathrm{La}=\mathrm{Late}, \mathrm{Li}=$ Light, Lo = Long, Me = Medium, ME = Mid Early, ML = Mid Late, Op = Opale, Ov = Oval, $\mathrm{P}=$ Pale, $\mathrm{R}=\mathrm{Round}, \mathrm{Ra}=\mathrm{Rather}, \mathrm{Sh}=\mathrm{Shallow}, \mathrm{V}=\mathrm{Very}, \mathrm{W}=$ White, $\mathrm{Y}=$ Yellow. 
every step of field sampling, four plants (clone) from every varieties in each replicate were analyzed. Whereas, in green house sampling, 5 pots were analyzed accordingly [7].

The samples were transferred into the lab, and the total fresh and dry weights were measured by drying for $48 \mathrm{~h}$, at $75^{\circ} \mathrm{C}$. For determining understudies factors, the following factors were measured for both the field and green house [2,8,9].

\section{1) Crop growth rate (CGR)}

$$
\mathrm{CGR}=(\mathrm{W} 2-\mathrm{W} 1)(\mathrm{T} 2-\mathrm{T} 1) \times \mathrm{GA}
$$

CGR is calculated based on $\mathrm{gr} / \mathrm{m}^{2}$.

W1 and W2 are the total dry weight in the first and second sampling. T1 and T2 are the times of sampling and GA is the sampling level based on square meter.

2) Net assimilation rate (NAR)

$$
\mathrm{NAR}=1 / \mathrm{LA} \times \mathrm{dw} / \mathrm{dt}
$$

NAR is the speed of photosynthesis based on $\mathrm{gr} / \mathrm{m}^{2}$ of LA, LA is the leaf area and dw/dt is the changes of dry weight of plant $\times$ time.

3) Leaf area index (LAI)

$$
\mathrm{LAI}=\mathrm{LA} / \mathrm{P}
$$

LAI is the leaf area of one side, which occupies the land. LA is the leaf area and P is the surface of sampled land based on square meter.

\section{4) Leaf area duration (LAD)}

$$
\mathrm{LAD}=(\mathrm{LA} 2+\mathrm{LA} 1) \times(\mathrm{T} 2-\mathrm{T} 1) / 2
$$

LAD is the largeness and leaf area based on growing time of product.

LA1 and LA2 are leaf area of plant in the first and second sampling. T1 and T2 are times of first and second sampling.

\section{5) Relative growth rate (RGR)}

$$
1 / \mathrm{W} \times \mathrm{DW} / \mathrm{DT}
$$

RGR is based on the changes of dry plant per day, $\mathrm{W}$ is the weight of dry plant, and DW/DT is the changes of dry weight of plant $\times$ time.

\section{6) Leaf area ratio (LAR)}

$$
\mathrm{LAR}=\mathrm{LA} / \mathrm{W}
$$

LAR is the relationship between photosynthesis tissue and the total weight of plant. LA is the leaf area and $\mathrm{W}$ is the total weight of plant.

\section{7) Specific leaf area (SLA)}

$$
\text { SLA }=\mathrm{LA} / \mathrm{LW}
$$

SLA is the leaf area and LW is the weight of leaves. For determining the height of plants at the time of harvesting. In each replication five plants (clones) were chosen randomly and the height of each was measured separetely. Then, the average was calculated. Also the same was with green house for 5 pots at the time.

On harvesting time, based on maturity, the varieties Ramose, Santeh, Shepody, Marfona in green house and field took placed on $28^{\text {th }}$ of May and $10^{\text {th }}$ of June 2010. Also, varieties like; Maradona, Milova, Santana, Boren were harvested on $8^{\text {th }}$ of June and $24^{\text {th }}$ of June2010. Agria, Granola, Cosima were harvested on $24^{\text {th }}$ of June and $9^{\text {th }}$ of July 2010. In harvesting time, the average of stem height and the length of root varieties were calculated. Also, the average of fresh and dry of stem and the root weights were calculated accordingly [10].

The data were subjected to statistical analysis by SAS software. Their averages were compared by danken multiple text ranges (DMRT). Also, the comparison and differences for variations were shown graphically [2].

Harvested tubers were classified based on into 3 tubers sizes, mini, medium and big respectively. The yield average and the number of tubers in every plant (clone) were calculated separately [11].

\section{Result and Discussion}

The results of phenological and morphological analysis of the varieties in field and green house are summarized in the following tables and figures, which are presented and discussed with the results of the other reporter as fallows accordingly.

\subsection{Leaf Area Index (LAI)}

The total leaf area of a bush based on the occupied land surface (LAI) had a great effect on plant growth and the final yield of dried material (Table 2, Figures 1 and 2) $(\mathrm{P}=0.01)$. The highest and lowest LAI in the field were related to varieties Cosima, Sante and the lowest one was related to Ramose. For varieties, Ramose, Sante, Shepody and Marfona, the highest of LAI was calculated before flowering period in the field and green house. But, for varieties, Santana, Maradona, Milova and Boren, the highest of LAI in field and green house was before flowering period. For varieties, Cosima, Granola, and Agria, was calculated at the end and at the beginning of the flowering periods. The highest LAI was observed in the field, because of the sufficient space for growing and also the large number of lateral stems. The average of LAI for understudied factors in field and green house were 3.23 and 1.37 for early maturing, 1.5 and 5.19 for mid maturing, and 6.12 and 1.9 for late maturing varieties respectively. All of the analysis showed positive coefficient among the highest LAI level of varieties ( $\mathrm{P}=$ 0.01 ). These results agreed with the findings of Kawakami and Gremew, which reports that, the growth factors including stems and leaf area are having positive correlation with yield measures [2,9]. 
Table 2. The average factors of potato varieties in the field and greenhouse conditions.

\begin{tabular}{|c|c|c|c|c|c|c|c|c|c|c|c|c|c|c|}
\hline \multirow{2}{*}{ Cultivars } & \multicolumn{2}{|c|}{ RGR } & \multicolumn{2}{|c|}{ NAR } & \multicolumn{2}{|c|}{ CGR } & \multicolumn{2}{|c|}{ SLA } & \multicolumn{2}{|c|}{ LAR } & \multicolumn{2}{|c|}{ LAD } & \multicolumn{2}{|c|}{ LAI } \\
\hline & $\mathrm{F}$ & G & $\mathrm{F}$ & G & $\mathrm{F}$ & G & $\mathrm{F}$ & G & $\mathrm{F}$ & G & $\mathrm{F}$ & G & $\mathrm{F}$ & G \\
\hline Ramose & $0.0671 d$ & 7.76d & $6.97 d$ & 7.76e & $16.93 \mathrm{~g}$ & $8.2 \mathrm{f}$ & $17.03 \mathrm{i}$ & 13.23b & $105 f$ & $82.6 b$ & 16.23e & $5.66 \mathrm{~g}$ & $3.25 \mathrm{ef}$ & $1.3 \mathrm{~d}$ \\
\hline Sante & $0.0676 \mathrm{c}$ & 7.98d & $6.44 \mathrm{f}$ & 7.98d & 16.16h & $9.15 \mathrm{e}$ & $18.04 \mathrm{~h}$ & $11.66 \mathrm{c}$ & $125 \mathrm{e}$ & 71.6d & $15.27 f$ & $5.85 f$ & $3.07 \mathrm{~g}$ & $1.31 \mathrm{~d}$ \\
\hline Shepody & $0.0681 \mathrm{~b}$ & 8.33bc & 7.99a & 8.33bc & $16.9 \mathrm{~g}$ & $8.28 \mathrm{f}$ & $22.36 \mathrm{e}$ & $13 b$ & 129d & $77.6 \mathrm{c}$ & $15.32 \mathrm{f}$ & 5.89e & $3.19 \mathrm{f}$ & $1.35 \mathrm{~cd}$ \\
\hline Marfona & $0.0681 b$ & $6.96 \mathrm{e}$ & $7.97 a$ & $6.96 \mathrm{e}$ & $18.08 \mathrm{e}$ & $9 e$ & $19.02 \mathrm{~g}$ & $11.76 \mathrm{c}$ & 130d & $87.4 a$ & $16.6 \mathrm{e}$ & $5.78 \mathrm{f}$ & $3.43 e$ & $1.4 \mathrm{c}$ \\
\hline Santana & $0.0676 \mathrm{c}$ & $9.12 \mathrm{a}$ & $6.76 \mathrm{e}$ & $9.12 \mathrm{a}$ & $22.8 \mathrm{c}$ & 9.93cd & $27 a$ & $13.25 b$ & $140 \mathrm{c}$ & $70.6 \mathrm{~d}$ & $28.21 \mathrm{c}$ & $8.54 \mathrm{c}$ & $5.17 d$ & $1.45 b$ \\
\hline Maradona & $0.0674 \mathrm{~d}$ & 8.33bc & $6.77 \mathrm{e}$ & 8.33bc & 22.11d & $11.07 \mathrm{a}$ & $20.05 f$ & $11.78 \mathrm{c}$ & $100 \mathrm{~g}$ & $62.2 \mathrm{~g}$ & $27.2 \mathrm{~d}$ & $8.16 \mathrm{~d}$ & $5.14 \mathrm{~d}$ & $1.5 b$ \\
\hline Milova & $0.0673 d$ & $8.44 b$ & $7.06 \mathrm{c}$ & $8.44 b$ & $23.45 b$ & $10.4 \mathrm{~b}$ & $17.32 \mathrm{i}$ & $13.25 b$ & 141c & $65 f$ & $27.27 \mathrm{~cd}$ & $8.14 d$ & $5.23 \mathrm{~d}$ & $1.48 \mathrm{~b}$ \\
\hline Boren & $0.0687 \mathrm{a}$ & 8.84a & $7.43 b$ & 8.84a & $24.26 a$ & $11.15 \mathrm{a}$ & $25.53 c$ & 13.57b & $167 b$ & $62 \mathrm{~g}$ & $27.27 d$ & $8.12 \mathrm{~d}$ & $5.2 \mathrm{~d}$ & $1.49 \mathrm{~b}$ \\
\hline Cosima & $0.0640 \mathrm{f}$ & 7.99d & $5.58 \mathrm{i}$ & 7.99d & $17.12 \mathrm{f}$ & $11.29 a$ & $25.52 c$ & $13.07 b$ & 131d & $87 a$ & 39.39a & 12.13a & $6.23 a$ & 1.89a \\
\hline Granola & $0.0663 \mathrm{e}$ & $8.48 \mathrm{~b}$ & $5.71 \mathrm{~h}$ & $8.48 b$ & 16.43gh & $10.24 b c$ & 26.31b & $14.86 a$ & 127e & $82.6 b$ & 37.07b & 12.13a & $6 c$ & $1.89 a$ \\
\hline Agria & $0.0674 \mathrm{~d}$ & 7.94d & $6.08 \mathrm{~g}$ & 7.94d & $17.85 \mathrm{e}$ & 9.73d & $24.64 d$ & 13.14b & $170 a$ & $82.8 b$ & 39.28a & 11.83b & $6.13 b$ & $1.85 a$ \\
\hline
\end{tabular}

Means followed by the same letter are not significantly different at the 0.01 level probability; F: Field, G: Greenhouse.

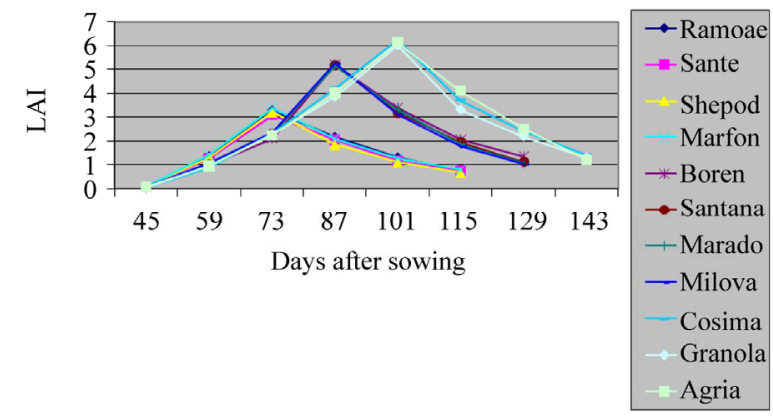

Figure 1. Shift of LAI in potato' varieties in field.

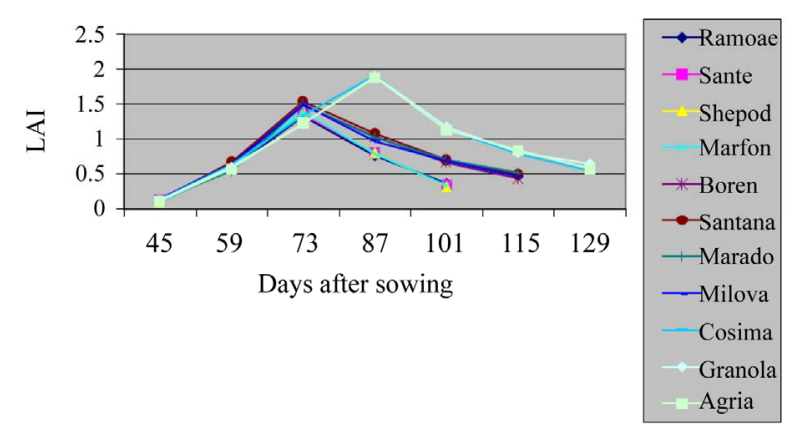

Figure 2. Shift of LAI in potato' varieties in greenhouse.

\subsection{Crop Growth Rate (CGR)}

There was a significant difference (in ratio of 1\%) among potato varieties in the field and green house (Table 2, Figures 3 and 4) $(P=0.01)$. The maximum of CGR in the field was belonged to Boren and the minimum to Sante variety. And, in green house, the maximum level was of Cosima and the minimum to Ramose. According to the

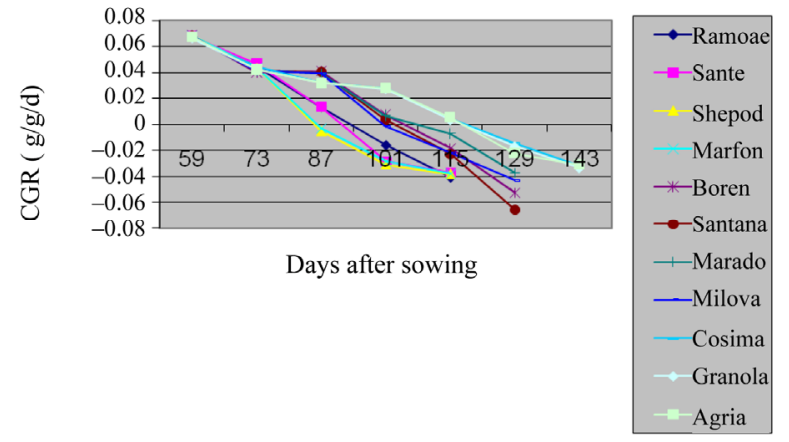

Figure 3. Shift of CGR in studied potato's varieties in field.

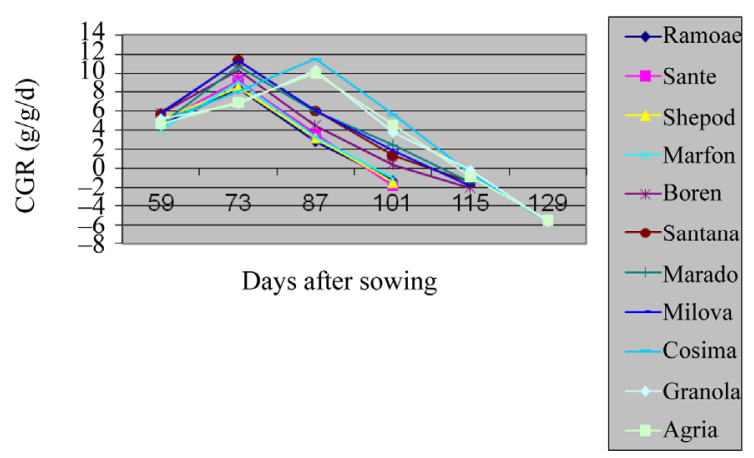

Figure 4. Shift of CGR in studied potato's varieties in greenhouse.

tables and figures, the CGR in the plant had a sigmoid trend. All the varieties in the field and green house had low trend at the early stages then, their trend were increased accordingly. Early maturing varieties, Ramose, Sante, Shepody, and Marfona reached their maximum CGR, before flowering in both the field and green house. 
Mid-maturity varieties, Santana, Maradona, Milova, and Boren reached the maximum level of CGR at the beginning of flowering and in green house before flowering. For the late maturing varieties Cosima, Granola, Agria maximum level of CGR was at the end of flowering. At the Stages after this period, the CGR was slowed down, because of reduction of pure absorption and leaves falling $[7,11,12]$. The increase of structural tissues in comparison to active merystemic tissues, the age of leaves, the reduction of leaf area and pure absorption and shading of upper leaves over lower leaves were all factors effecting on CGR among Solanum tuberosum varieties in the field and green house [13].

\subsection{Net Assimilation Rate (NAR)}

The maximum level of NAR in the field was of to the beginning of the growth season, because of being small plant and the radiation of the sun over all leaves. But, over the time, the size of leafs area increased in Shepody, Marfona varieties and the minimum level was in Cosima (Table 2, Figures 5 and 6) $(\mathrm{P}=0.01)$. Also, in green house the maximum of NAR was belonged to Santana and the minimum in Marfona. At the beginning of the growth season, the NAR was the highest, because of slow plant growth and the radiation of the sun over all the leaves. But, over the time, the size of leaves area were increased and, they made shadow over lower leaves

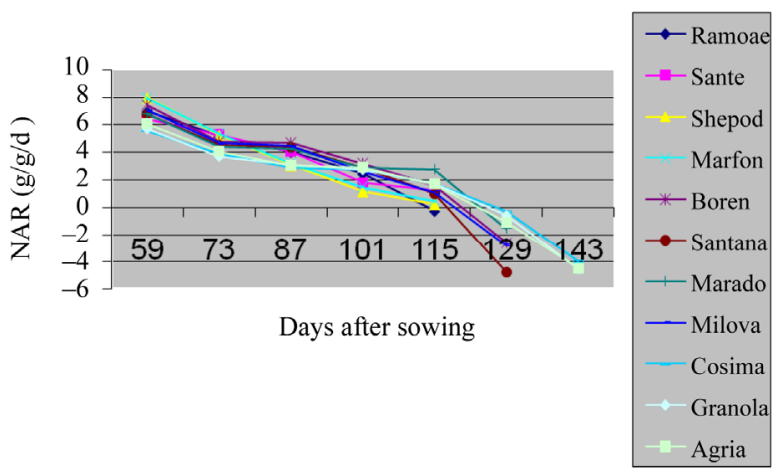

Figure 5. Shift of NAR potato varieties in the field.

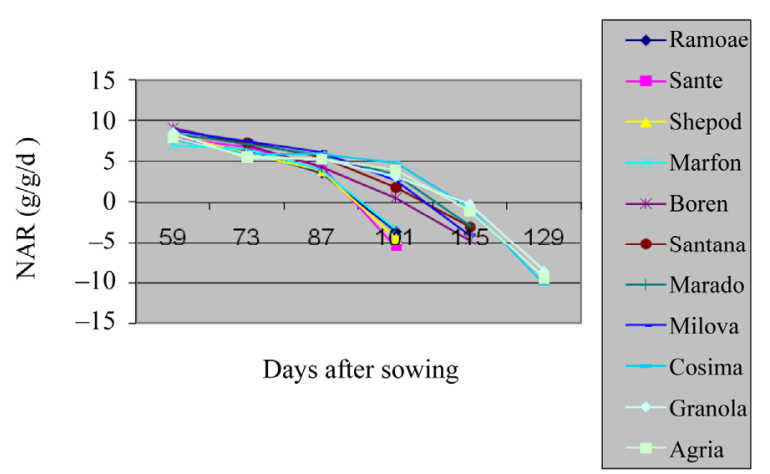

Figure 6. Shift of NAR in potato's varieties in greenhouse. and also, the aged leaves made lower photosynthesis process. At the end of growth the period, NAR becomes so low that, made the resulted factors negative. This was because of increasing temperature, leaf falling and the low level of photosynthesis. These results are in agreement with the analysis of the other workers [12].

\subsection{Leaf Area Ratio (LAR)}

There was a significant difference among varieties in the field and green house (Table 2, Figures 7 and 8) $(\mathrm{P}=$ 0.01). The harvest LAR in field and green house was of Agria and Marfona whereas, the lowest was of Maradona and Boren. LAR is the largest of photosynthesis area in plant. There are certain reports indicating reduction of LAR in different $S$. tuberosum varieties showed this reality that, the growth of tuber consumed more photosynthesis materials of plant. This matter caused at the beginning of growth period. LAR had decreasing trend in all $S$. tuberosum varieties [13,14].

\subsection{Specific Leaf Area (SLA)}

The maximum level of SLA in the field and green house was of Santana and Granola respectively (Table 2 and Figures 9 and 10) $(P=0.01)$. The lowest of SLA in the field and green house was of Ramose and Sante respectively. Actually, the total weight of any leaf was lower

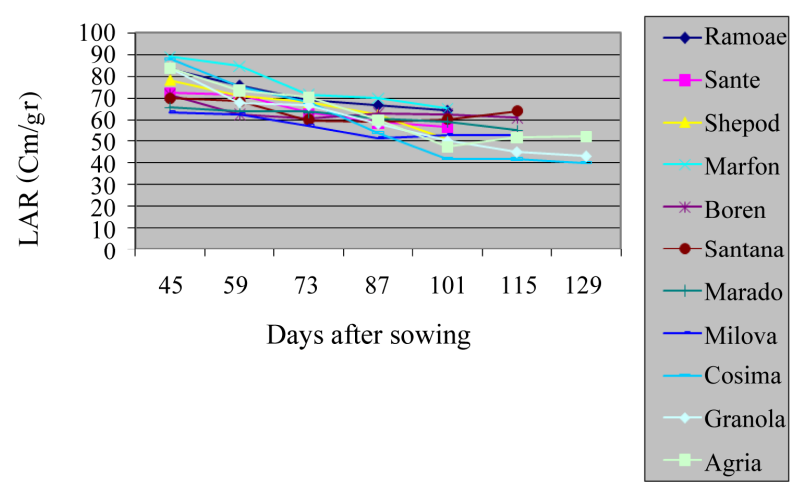

Figure 7. Shift of LAR in potato varieties in the field.

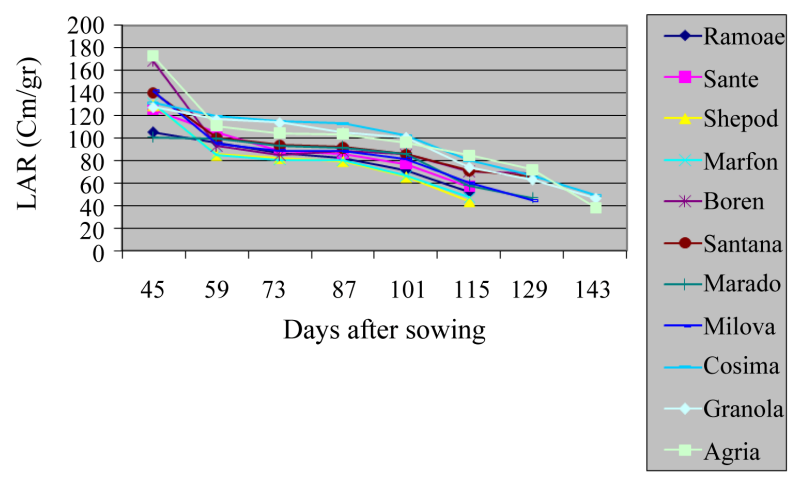

Figure 8. Shift of LAR in potato varieties in greenhouse. 

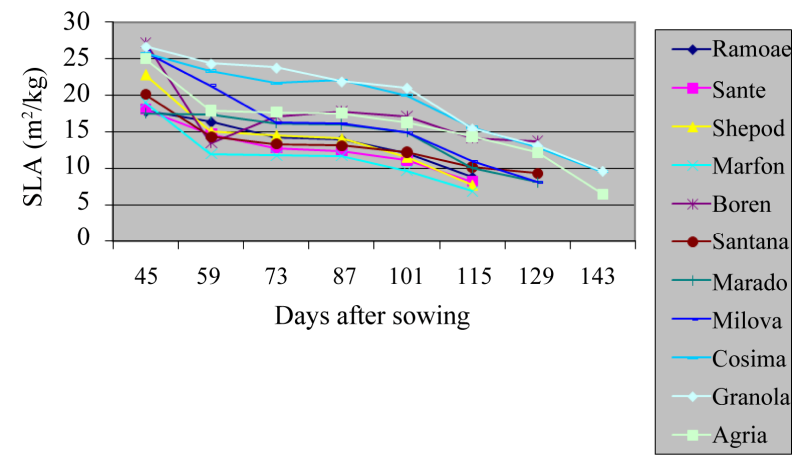

Figure 9. Shift of SLA in potato varieties in the field.

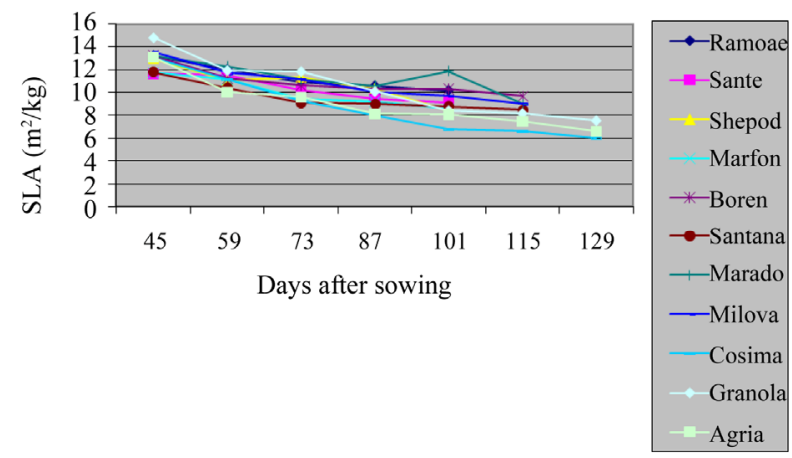

Figure 10. Shift of SLA in potato varieties in greenhouse.

than the ratio of their specific leaf area at the beginning of the growth. But, during the growing period, the total weight of plant was increased, and it caused the reduction of SLA. The SLA of varieties in the field was significantly different from the varieties in green house $(\mathrm{P}=$ 0.01 ). As the result, the leaves of $S$. tuberosum varieties in green house were thicker than in the field, which agrees with other findings $[13,14]$.

\subsection{Leaf Area Duration (LAD)}

The maximum level of LAD in the field and greenhouse was found in Cosima, Granola and, the lowest ones in Sante and Ramose respectively (Table 2 and Figures 11 and 12) $(P=0.01)$. LAD of potato varieties in the field is more than green house which is in agreement with the other reporters $[10,15,16]$.

\subsection{The Effect of Varieties on the Number of Days from Sowing to Flowering Stage}

The effect of varieties on the number of days was significant $(P=0.01)$ as shown in Table 3. Marfuna had the larger number of the days from sowing to germination, wheres Agria was reverse. Cosima had the larger number of days from sowing to tuberization and Ramose was reserve than that. Also, Cosima had the large number of days from calendar date to flowering whereas, Cosima was vice versa in both the field and green house. These

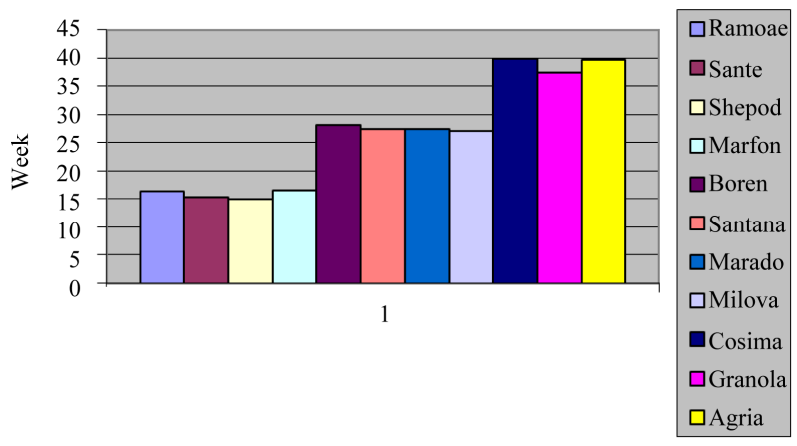

Figure 11. Shift of LAD in studied potato's varieties in field.

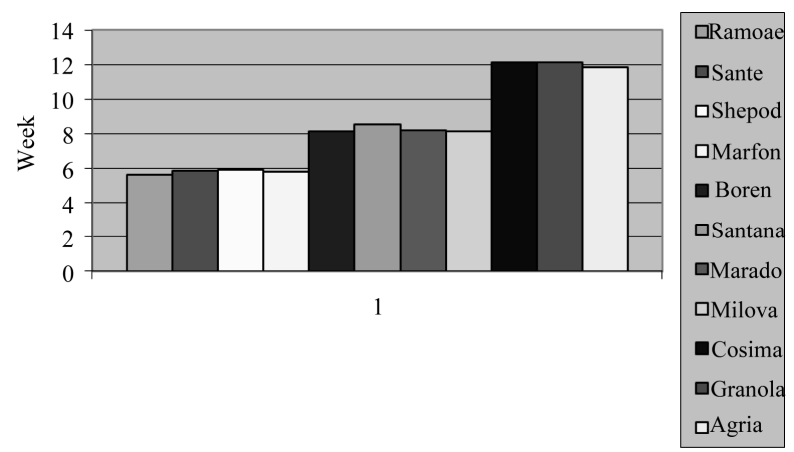

Figure 12. Shift of LAD in studied potato's varieties in greenhouse.

differences among varieties were because of their genetic of late or early maturing and also their responses to the length of the days and the temperatures of the environment. There are reports indicating that, in the varieties, which had germination process lately, tuberization and flowering are happened early $[6,17]$.

\subsection{The Effect of Varieties on the Number and Length of Stems}

A month after germination, the varieties had a significant effect on the number and the length of stems per plant (P $=0.01$ ) (Tables 3-5). In the number of stems, Agria had the maximum density of stems and Sante with the lowest density. Agria had the longest and Ramose the shortest stem a month after germination. The rest of varieties had no any significant differences. The difference among varieties in the length of the main stem, was varying. That is because of their genetic differences that shows, the distance between nodes and the number of nodes in stem $[18,19]$.

\subsection{The Analysis of Yield Changes among Varieties in the Field}

Among different varieties, in case of marketing performance, there was a significant difference probability 
Table 3. Variance analysis of potato varieties factors in the field.

\begin{tabular}{ccccccccc}
\hline & & \multicolumn{5}{c}{ Mean Square (MS) } \\
\cline { 2 - 8 } & & \multicolumn{2}{c}{ The length of the longest $(\mathrm{cm})$} & Number of stems in a bud & \multicolumn{2}{c}{ The number of days from calendar date to } \\
\hline $\begin{array}{c}\text { Source of } \\
\text { variation (SV) }\end{array}$ & $\begin{array}{c}\text { Degrees of } \\
\text { freedom }\end{array}$ & Maturity & $\begin{array}{c}\text { A month after } \\
\text { germinat ion }\end{array}$ & Maturity & $\begin{array}{c}\text { A month after } \\
\text { germination }\end{array}$ & Flowering & Tuberization & Germination \\
\hline Treatment & 10 & $388.39^{* *}$ & $215.17^{* *}$ & $3.59^{* *}$ & $2.61^{* *}$ & $19.85^{* *}$ & $26.04^{* *}$ & $19.64^{* *}$ \\
Error & 33 & 5.39 & 2.55 & 0.42 & 0.18 & 0.45 & 0.4 & - \\
Total & 43 & - & - & - & - & - & 0.99 & - \\
CV\% & - & 2.48 & 2.05 & 13.14 & 13.97 & 0.99 & 0.99 & 4.2 \\
\hline
\end{tabular}

${ }^{* *}$ Significant at 0.01 level of probability.

Table 4. Variance analysis of potato varieties factors in the green house.

\begin{tabular}{|c|c|c|c|c|c|c|c|c|}
\hline \multirow[b]{3}{*}{$\begin{array}{c}\text { Source of } \\
\text { variation (SV) }\end{array}$} & \multirow[b]{3}{*}{$\begin{array}{l}\text { Degrees of } \\
\text { freedom }\end{array}$} & \multicolumn{7}{|c|}{ Mean Square (MS) } \\
\hline & & \multicolumn{2}{|c|}{ The length of the longest $(\mathrm{cm})$} & \multicolumn{2}{|c|}{ Number of stems in a bud } & \multicolumn{3}{|c|}{ The number of days from calendar date to } \\
\hline & & Maturity & $\begin{array}{l}\text { A month after } \\
\text { germination }\end{array}$ & Maturity & Maturity & $\begin{array}{l}\text { A month after } \\
\text { germination }\end{array}$ & Maturity & Maturity \\
\hline Treatment & 10 & $137.92^{* *}$ & $56.65^{* *}$ & $4.15^{* *}$ & $4.09^{* *}$ & $26.01^{* *}$ & $14.75^{* * *}$ & $13.37^{*+}$ \\
\hline Error & 44 & 4.09 & 2.29 & 0.48 & 0.54 & 0.61 & 0.59 & 0.63 \\
\hline Total & 54 & - & - & - & - & - & - & - \\
\hline $\mathrm{CV} \%$ & - & 3.93 & 4.23 & 12.94 & 19.81 & 1.48 & 1.52 & 4.18 \\
\hline
\end{tabular}

${ }^{* *}$ Significant at 0.01 level of probability.

Table 5. The mean comparison of potato varieties factors in field and green house.

\begin{tabular}{|c|c|c|c|c|c|c|c|c|c|c|c|c|c|c|}
\hline \multirow{3}{*}{ Cultivars } & \multicolumn{4}{|c|}{ The length of the longest $(\mathrm{cm})$} & \multicolumn{4}{|c|}{ Number of stems in a bud } & \multicolumn{6}{|c|}{ The number of days from calendar date to } \\
\hline & \multicolumn{2}{|c|}{ Maturity } & \multicolumn{2}{|c|}{$\begin{array}{l}\text { A month after } \\
\text { germination }\end{array}$} & \multicolumn{2}{|c|}{ Maturity } & \multicolumn{2}{|c|}{$\begin{array}{l}\text { A month after } \\
\text { germination }\end{array}$} & \multicolumn{2}{|c|}{ Flowering } & \multicolumn{2}{|c|}{ Tuberization } & \multicolumn{2}{|c|}{ Germination } \\
\hline & $\mathrm{F}$ & G & F & G & $\mathrm{F}$ & G & F & G & $\mathrm{F}$ & G & $\mathrm{F}$ & G & F & G \\
\hline Ramose & $44 c$ & $87.5 \mathrm{c}$ & $29.5 c$ & $4 \mathrm{~b}$ & $2.2 \mathrm{~b}$ & $4 \mathrm{~b}$ & $2.2 \mathrm{~b}$ & $2.25 b$ & $50 \mathrm{c}$ & $64.5 \mathrm{c}$ & $47 \mathrm{c}$ & $60 c$ & $20 \mathrm{a}$ & $25.5 a$ \\
\hline Sante & $46.2 \mathrm{c}$ & $89.25 c$ & $31.6 \mathrm{c}$ & $3.8 \mathrm{bc}$ & $2 b$ & $3.8 \mathrm{~b}$ & $2 b$ & $2 b$ & $50.6 \mathrm{c}$ & $65.25 c$ & $48.2 \mathrm{c}$ & $61.25 \mathrm{c}$ & $20.6 \mathrm{a}$ & $26.25 a$ \\
\hline Shepody & $47 c$ & $90.25 c$ & $31 \mathrm{c}$ & $4.25 b$ & $2.6 \mathrm{~b}$ & $4.25 b$ & $2.6 \mathrm{~b}$ & $2.25 b$ & $50.4 \mathrm{c}$ & $64.7 \mathrm{c}$ & $48 c$ & $61 c$ & $21.6 \mathrm{a}$ & $27.25 a$ \\
\hline Marfona & $48 c$ & $91.5 \mathrm{c}$ & $30 c$ & $4.5 \mathrm{~b}$ & $2.6 \mathrm{~b}$ & $4.5 \mathrm{~b}$ & $2.6 \mathrm{~b}$ & $2.2 \mathrm{~b}$ & $50.6 \mathrm{c}$ & $65 c$ & $47.8 \mathrm{c}$ & $60.25 c$ & $21 \mathrm{a}$ & $26.25 a$ \\
\hline Santana & $50.8 \mathrm{~b}$ & $98 b$ & $34.6 \mathrm{~b}$ & $5.5 \mathrm{ab}$ & $4 a$ & $5.5 b$ & $4 a$ & 3.5a & $52.8 \mathrm{~b}$ & $67.25 \mathrm{~b}$ & $50.8 \mathrm{~b}$ & $65.75 b$ & $17.8 \mathrm{~b}$ & $21.25 b$ \\
\hline Maradona & $51.2 \mathrm{~b}$ & $96.5 b$ & $35 b$ & $6 a$ & $4.8 \mathrm{a}$ & $6 a$ & $4.8 \mathrm{a}$ & $3.5 a$ & $52.6 \mathrm{~b}$ & $67.75 b$ & $51 b$ & $65 b$ & $17.8 \mathrm{~b}$ & $23.25 b$ \\
\hline Milova & $50.6 \mathrm{~b}$ & $97 \mathrm{~b}$ & $34 b$ & $6 a$ & $4.4 \mathrm{a}$ & $6 a$ & $4.4 \mathrm{a}$ & $4 a$ & $53 b$ & $67 \mathrm{~b}$ & $51.4 \mathrm{~b}$ & $65.75 b$ & $18 b$ & $22.5 b$ \\
\hline Boren & $50 \mathrm{~b}$ & $95 b$ & $33 b$ & 6.1a & $4 a$ & $6.1 \mathrm{a}$ & $4 a$ & $3.75 a$ & $52.2 \mathrm{~b}$ & $67.25 b$ & $50.6 \mathrm{~b}$ & $65.5 b$ & $17.8 \mathrm{~b}$ & $21.25 b$ \\
\hline Cosima & $57.8 \mathrm{a}$ & 105.75a & 39.6a & $6.25 a$ & $4.6 \mathrm{a}$ & $6.25 a$ & $4.6 a$ & 3.5a & $55.6 \mathrm{a}$ & $71 \mathrm{a}$ & $52.8 \mathrm{a}$ & $68 a$ & $17.8 \mathrm{~b}$ & $22.25 b$ \\
\hline Granola & $58.2 \mathrm{a}$ & 105.25a & $38.6 a$ & $6.2 \mathrm{a}$ & $4.2 \mathrm{a}$ & $6.2 \mathrm{a}$ & $4.2 \mathrm{a}$ & $4 a$ & $55.4 a$ & $69.5 a$ & $52.6 \mathrm{a}$ & 67.1a & $18.6 \mathrm{~b}$ & $23.5 b$ \\
\hline Agria & $58.6 a$ & $108.25 a$ & 39.8a & $6.35 a$ & $5.1 \mathrm{a}$ & $6.35 a$ & $5.1 \mathrm{a}$ & $4.2 \mathrm{a}$ & $55.4 \mathrm{a}$ & $70 a$ & $52 a$ & $67.75 a$ & $17 b$ & $21 b$ \\
\hline
\end{tabular}

Followed by the same letter are not significantly different at the 0.01 level of probability according to Duncan test. F: Field, G: Glasshouse.

$(\mathrm{P}=0.01)$. Tables 6 and 7 show that, the maximum marketing yield among $S$. tuberosum varieties was belonged to Agria and the lowest one to Sante. The maximum level of tuber production was of Maradona and the lowest one in Sante, which is in agreement with others reports [5,20].

\subsection{Average Number and the Weight of Potato Tubers}

The maximum tuber numbers were observed in Boren and Cosima in the field and Agria in green house respectively (Tables 8 and 9) $(\mathrm{P}=0.01)$. The lowest tuber numbers per plant was of to Shepody in the field and Boren 
Table 6. Variance analysis of potato varieties in the field.

\begin{tabular}{cccccc}
\hline \multirow{2}{*}{$\begin{array}{c}\text { Source of variation } \\
\text { (SV) }\end{array}$} & $\begin{array}{c}\text { Degrees of } \\
\text { freedom }\end{array}$ & Big size tubers & Medium tubers & Small tubers & Total yield \\
\cline { 3 - 6 } Treatment & 10 & $64.63^{* *}$ & $87.18^{* *}$ & $8.85^{* *}$ & $183.81^{* *}$ \\
Error & 33 & 17.74 & 15.33 & 0.73 & 11.38 \\
Total & 43 & - & - & - & - \\
CV\% & - & 64.51 & 20.18 & 28.47 & 8.82 \\
\hline
\end{tabular}

${ }^{* *}$ Significant at 0.01 level of probability.

Table 7. The comparison of yield average of varieties in the field.

\begin{tabular}{|c|c|c|c|c|c|}
\hline Varieties & Big size tubers & Medium tubers & Seed tubers & Mini tuber & Total yield \\
\hline Ramose & 11.49ab & $17.01 \mathrm{~cd}$ & $8.28 b c$ & $2.23 \mathrm{~b}$ & 39.02cd \\
\hline Sante & $1.66 \mathrm{c}$ & $12.79 d$ & $9.05 b c$ & $2.13 \mathrm{~b}$ & 25.64de \\
\hline Shepody & $3.77 b c$ & 20.85bcd & $6.38 c$ & $1.96 \mathrm{~b}$ & 32.98de \\
\hline Marfona & 5.76abc & $15.41 d$ & $7.05 \mathrm{bc}$ & $1.6 b$ & 29.82ef \\
\hline Santana & 11.46ab & $14.26 \mathrm{~d}$ & 11.3abc & $3.22 \mathrm{~b}$ & 40.19bcd \\
\hline Milova & $2.68 c$ & $26.75 a$ & 11.87abc & $3.13 b$ & 44.45abc \\
\hline Boren & $3.7 \mathrm{c}$ & 25.55ab & 8.39bc & $2.54 b$ & 40.14bcd \\
\hline Cosima & 6.02abc & 18.73abcd & $16.21 \mathrm{a}$ & $5.43 a$ & 46.4ab \\
\hline Granola & $2.23 c$ & 19.75abcd & $10.74 b c$ & $3.11 b$ & 35.84de \\
\hline Agria & $4.07 \mathrm{bc}$ & 24.73ab & 12.43ab & $6.13 a$ & 47.37a \\
\hline
\end{tabular}

Followed by the same letters are not significantly different at the 0.01 level of probability.

Table 8. Variance analysis of the yield factors in the field and green house.

\begin{tabular}{|c|c|c|c|c|c|c|}
\hline \multirow{3}{*}{$\begin{array}{l}\text { Source of variation } \\
\text { (SV) }\end{array}$} & \multicolumn{6}{|c|}{ Mean square (MS) } \\
\hline & \multicolumn{2}{|c|}{ Degrees of freedom } & \multicolumn{2}{|c|}{$\begin{array}{c}\text { Average } \\
\text { No. of tubers per plant }\end{array}$} & \multicolumn{2}{|c|}{$\begin{array}{c}\text { Average } \\
\text { weight of tubers per plant }\end{array}$} \\
\hline & G & G & $\mathrm{F}$ & $\mathrm{F}$ & G & $\mathrm{F}$ \\
\hline Treatment & 10 & $48.73^{* *}$ & $480.75^{* *}$ & $14.23^{* *}$ & $73.48^{* *}$ & $480.75^{* *}$ \\
\hline Error & 44 & 4.91 & 104.15 & 1.09 & 4.91 & 104.15 \\
\hline Total & 54 & - & - & - & - & - \\
\hline CV\% & - & 10.75 & 12.44 & 11.6 & 10.75 & 12.44 \\
\hline
\end{tabular}

*** Significant at 0.01 level of probability; F: Field, G: Glasshouse.

Table 9. The comparison of yield factors in the field and green house.

\begin{tabular}{|c|c|c|c|c|}
\hline \multirow[t]{2}{*}{ Varieties } & \multicolumn{2}{|c|}{$\begin{array}{c}\text { Average } \\
\text { No. of tubers per plant }\end{array}$} & \multicolumn{2}{|c|}{$\begin{array}{c}\text { Average } \\
\text { weight of tubers per plant (gr) }\end{array}$} \\
\hline & G & $\mathrm{F}$ & G & $\mathrm{F}$ \\
\hline Ramose & $1.8 \mathrm{bc}$ & 8.35bc & $14 \mathrm{~g}$ & 89.02ab \\
\hline Sante & $1.4 \mathrm{c}$ & $6.95 \mathrm{~cd}$ & $24.5 b$ & $71.6 \mathrm{~b}$ \\
\hline Shepody & $3.6 b$ & 8.35bc & 20d & 75.77b \\
\hline Marfona & $2.6 \mathrm{bc}$ & $6.10 \mathrm{~d}$ & 21.48cd & 93.32ab \\
\hline Santana & $2.2 \mathrm{bc}$ & $9.45 b$ & $17.44 \mathrm{e}$ & $80.52 b$ \\
\hline Maradona & $3.2 \mathrm{bc}$ & 6.80cd & $17.04 \mathrm{e}$ & 107.5a \\
\hline Milova & $1.4 \mathrm{C}$ & $11.55 \mathrm{a}$ & $17 \mathrm{fg}$ & $72.7 b$ \\
\hline Boren & $2.2 \mathrm{bc}$ & $9.40 \mathrm{~b}$ & 21.96c & $81.5 b$ \\
\hline Cosima & $2.4 \mathrm{bc}$ & $11.55 \mathrm{a}$ & $26.2 \mathrm{a}$ & 76.17b \\
\hline Granola & $2.2 \mathrm{bc}$ & $9.35 b$ & $20.8 \mathrm{~cd}$ & $71.81 \mathrm{~b}$ \\
\hline Agria & $5.4 \mathrm{a}$ & $10.95 a$ & 25.67ab & $82.25 b$ \\
\hline
\end{tabular}

Followed by at least one same letter are not significantly different at the 0.01 level of probability according to Duncan test. 
and Sante in green house. Also, the maximum average of tuber weight was found in Maradona in the field and Cosima green house. The minimum tuber weights in the field and green house was of Sante and Ramose varieties respectively. Which, confirmed the findings by other researchers [5,20,21].

\section{REFERENCES}

[1] E. G. Cutter, "Structure and Development of the Potato Plant,” In: P. M. Harris, Ed., The Potato Crop, Chapman and Hall, London, 1982, pp. 70-152. doi:10.1007/978-94-011-2340-2_3

[2] J. Kawakami, K. Iwama, Y. Jitsuyama and X. Zheng, "Effect of Cultivar Maturity Period on the Growth and Yield of Potato Plants Grown from Micro Tubers and Conventional Seedtubers," American of potato Research, Vol. 81, 2004, pp. 327-333.

[3] S. B. Jones and A. E. Luchsinger, "Plant Systematic," 2nd Edition, McGraw-Hill Book Company, New York, 1987, p. 512.

[4] R. J. Dclorit and L. J. Greub, “Crop Production,” 5th Edition, Prentic-Hall Inc., New York, 1984, p. 768.

[5] A. A. Abdullah and K. W. Knutson, "Field and Greenhouse Tuberization of Six Potato Cultivars Grown from in Vitro Plantlets,” Journal of Agricultural Science, Vol. 1, 1994, pp. 79-86.

[6] D. C. E. Wurr, J. R. Fellows and E. R. Allen, "Determination of Optimum Tuber Density in the Potatovarieties, Pentland, Squir, Cara, Estima, Maris Piper and King Edward,” Journal of Agricultural Science, Vol. 19, No. 1, 1992, pp. 35-99. doi:10.1017/S0021859600071525

[7] A. Isoda, K. Nakaseko, K. Gotoh and S. Nishibe, "Productivity of Some Hybrid Strains between Andigena and Tuberosum in Potato,” Japanese Journal of Crop Science, Vol. 56, No. 3, 1987, pp. 379-386.

[8] F. B. Gardner, T. B. Pearce and R. L. Mitchen, "Physiological of Crop Plants,” Lowa State University Press, Ames, 1985, pp. 186-208.

[9] B. Gremew, J. M. Stey and J. G. Annandal, "Evolution of Growth Performance and Dry Matter Partitioning of Four Processing Potato (Solanumtuberosum) Cultivars," New Zealand Journal of Crop and Horticultural Science, Vol. 35, 2007, pp. 385-393.

[10] P. L. Kooman and R. Rabbinge, “An Analysis of the Relation between Dry Matter Allocation to the Tuber and Earliness of a Potato Crop," Annals of Botany, Vol. 77, No. 3, 1996, pp. 335-242. doi:10.1006/anbo.1996.0027

[11] F. Borrego, M. Fernandez., A. Lopez, V. Parga, M. Murillo and A. Carvajal, "Growth Analysis in Seven Po- tato Cultivars (Solanumtuberosum)," Agronomia Mesoamerican, Vol. 11, No. 1, 2000, pp. 145-149.

[12] R. J. Fonseka, K. Asanuma, A. Kustani, A. K. Ghosh and K. Ueda, "Growth and Yield of Potato Cultivarsin Spring Sowing," Japan Journal of Crop Science, Vol. 65, No. 2, 1996, pp. 269-276.

[13] L. Smeets and F. Garretson, "Growth Analysis of Tomato Genotypes Grown under Low Night Temperatures and Low Light Intensity,” Euphyica, Vol. 35, 1986, pp. 701715. doi:10.1007/BF00028578

[14] D. J. Midmore and R. K. Prange, "Growth Responses of Two Solanum Species of Contrasting Temperatures and Irradiance Levels: Relations to Photosynthesis, Dark Respiration and Chlorophyll Fluorescence," Annals of Botany, Vol. 69, No. 1, 1992, pp. 13-20.

[15] J. E. Board, B. G. Hartville and A. M. Sexton, "Branch Dry Weight in Relation to Yield Increases in NarrowRow Soybean,” Agronomy Journal, Vol. 82, No. 3, 1990, pp. 540-544. doi:10.2134/agronj1990.00021962008200030021x

[16] R. Gorden, D. M. Brown and M. A. Dixon, "Estimating Potato Leaf Area Index for Specific Cultivars,” Potato Research, Vol. 40, No. 3, 1997, pp. 251-266. doi:10.1007/BF02358007

[17] M. J. Morrison, D. W. Stewart and P. B. E. M. C. Vetty, "Maximum Area Expansion Rate and Duration of Summer Rapeleaves," Canadian Journal of Plant Science, Vol. 72, No. 1, 1992, pp. 117-126. doi:10.4141/cjps92-012

[18] D. C. E. Wurr, J. R. Fellows and E. R. Allen, “An Approach to Detraining of Optimum Tuber Planting Density for Production of Tubers in Real Potato Varieties,” Journal of Agricultural Science, Vol. 120, 1993, pp. 63-70. doi:10.1017/S0021859600073597

[19] O. P. Ifenkwe and E. J. Allen, "Effects of Row Width and Planting Density on Growth and Yield of Two Main Croppotato Varieties. I. Plant Morphology and Dry Matter Accumulation Relationships with Above Ground Stem,” Journal of Agricultural Science, Vol. 91, 1978, pp. 256-269.

[20] W. J. M. Lommen, "Causes for Low Tuber Yield of Transplants from in Vitro Potato Plantlets of Early Cultivars after Field Planting,” Journal of Agricultural Science, Vol. 13, 1999, pp. 275-284. doi:10.1017/S002185969900698X

[21] S. Ahmed Ali, M. M. Alam and V. Souza Machado, "Potato Minituber Production from Modal Cuttings Compared to Whole in Vitro Plantlets Using Low Volume Media in a Greenhouse,” Potato Research, Vol. 38, 1994, pp. 69-76. 